\title{
Impact of Selected Insolvency Indicators on the Recoveries of Creditors' Claims Against Closed Banks in the Philippine Context
}

\author{
Ruben Mediona Nayve \\ La Consolacion College, Manila, Philippines \\ Marinor Gallardo Quintilla, Enrico Lingasin Torres \\ University of Santo Tomas, Manila, Philippines
}

\begin{abstract}
Banks play a pivotal role in an emerging economy. They mirror the country's political and economic status. The more savings deposited in banks would mean the availability of cash provided to users of funds. On the other hand, their closure affects the creditors. The goals of the study include the minimization of losses imposed on creditors and the expeditious recoveries of their claims against the closed banks' assets. The study proved on the four significant impacts of selected insolvency indicators on the recoveries of creditors' claims against the assets of closed banks under the Philippine context from 1961 to 2011. The study uses various methods such as Pearson product-moment correlation coefficient to establish the strength of association of the independent variable to the dependent variable and time series technique (moving average and trend forecasting) in order to observe the pattern of data over a known period of time. Using the regression analysis, the researchers were able to establish a regression model. The ANOVA test, $f$-test, and $R^{2}$-test were used to prove the model's goodness-of-fit, the significance of the predictors, and verification of the assumption of regression hold. Empirical evidence reveals that capital to estimated realizable value of assets ratio (ERVA) and debt to assets ratio (with respect to ERVA) were significant predictors of recovery. Further, the presence of high leverage on banks indicates that their liabilities exceed the value of their realizable assets. Thus, these banks fail to meet their maturing obligations, hence, imposing losses on the uninsured depositors and other creditors.
\end{abstract}

Keywords: insolvency, realizable asset, liquidation, recoveries

\section{Introduction}

Banking is a business activity which engages in accepting deposits for relending purposes for profit. It plays an integral role in the financial system. A stable banking system fosters public confidence in banks. It is characterized by its ability to protect and safeguard the deposits. The systemic shocks evident in the US and Europe led to close coordination between deposit insurers and other bank regulators. In the Philippines, to

Ruben Mediona Nayve, Ph.D., professor, La Consolacion College, Manila, Philippines.

Marinor Gallardo Quintilla, CPA, Ph.D., lecturer, University of Santo Tomas Graduate School, Manila, Philippines.

Enrico Lingasin Torres, Ph.D., associate professor, University of Santo Tomas Graduate School, Manila, Philippines.

Correspondence concerning this article should be addressed to Ruben Mediona Nayve, La Consolacion College, No. 8 Mendiola Street, San Miguel, Manila, Philippines 1005. E-mail: nayvejr@yahoo.com. 
ensure the safety of deposits, all banks licensed by Bangko Sentral ng Pilipinas (BSP) to operate in the Philippines are mandated to be members of the Philippine Deposit Insurance Corporation (PDIC) (2003). This study aims to minimize the losses imposed on the creditors and the expeditious recoveries of their claims against the closed banks' assets through the determination of the impact of selected insolvency indicators on the recoveries of creditors' claims against the assets of closed banks under Philippine context. To attain this goal, this paper should provide an empirical evidence to encourage bank regulators to prepare bills that include amendments on laws covering bank closures for presentation to the Philippine Senate and House of Representatives.

The Philippine banking structure encompasses: (1) universal banks (UBs), also known as expanded commercial banks (EKBs); (2) commercial banks (KBs); (3) thrift banks (TBs), composed of savings and mortgage banks, private development banks, stock savings, and loan associations; (4) rural banks (RBs); (5) cooperative banks (Coop Banks); (6) Islamic banks; and other classifications of banks as determined by the Monetary Board (MB) of BSP.

The two bank regulators in the Philippines include BSP and PDIC. BSP operates as the primary regulator of banks while PDIC is considered as a co-regulator of banks. Under the BSP charter, it is tasked to provide policy directions in the areas of money, banking and credit and shall have supervision over the operations of banks. The MB of BSP is the policy making body (RA No. 7653). The supervising and examining department head, personally or by deputy, conducts an annual examination of each bank operating in the Philippines. It employs a CAMELS Rating System (Capital Adequacy, Asset Quality, Management, Earnings, Liquidity and Sensitivity to Market Risk) wherein a rating of five is highest and one is the lowest. Further, MB also prescribes a minimum capitalization for each bank classification.

Conversely, PDIC was originated by RA No. 3591 which is directed to perform three roles, namely: (1) as co-regulator of banks, (2) as state deposit insurer, and (3) as Mandatory Receiver and Liquidator. Upon the acceptance of the MB Resolution, PDIC takes over the closed bank. One of the significant tasks of PDIC as receiver is to recommend to the $\mathrm{MB}$ whether to rehabilitate or to liquidate the closed bank. When the MB finds the receiver's recommendation to liquidate the bank as commendable, it will order the liquidation of the bank and appoint PDIC as liquidator of such bank. As liquidator, PDIC performs the following roles: (1) files with the Regional Trial Court a petition for assistance in the bank liquidation, (2) converts bank assets into money, and (3) pays the bank's obligations under Court's order, in accordance with the rules on concurrence and preference of credit under the Civil Code of the Philippines (RA No. 386).

\section{Theories and Hypotheses}

This study is anchored on the theory of capital structure such as net income theory, net operating income theory, traditional theory, and the Modigliani and Miller (MM) Trade-off Theory of Leverage. Further, the investment theory - portfolio theory plays an important role in the study. Advocates of theories of capital structure showed the significance of having an adequate bank capital. In the article of Kaufman (2004), banks are considered "failed", when their obligations are greater than their assets. Samad (2011) in his article disclosed that bank capital is important in a firm because of the following reasons: (1) It provides security to creditors and users of fund, and (2) it provides funds to back-up the operation of banks including the acquisition of assets. Maintaining solvency is used to safeguard the interests of creditors (Morris \& Shin, 2008). Diamond and Rajan (2000) indicated in their study that an adequate capital reduces financial anguish. This was supported 
by another author stating that a well-capitalized bank faces lower costs of going bankrupt (Vyas, Singh, \& Yadav, 2008). Capital is essential to the perpetual continuity of a bank going concern (Vyas et al., 2008). The study of Moore (2011) found that adequate capital serves as an early warning tool by the bank regulators and owners of banks. Capital was used to predict distressed banks and minimize the impact of their failure. In the study of Mitchener (2005), adequate bank capital is considered as the main form of protection for depositors. Bautista (2005) stated in her study that it is important for a bank to be closed early at a positive level of capital to prevent systemic risks. Hogan and Sharpe (1990) argued in their study that using historical cost as measurement will be ambiguous towards the true banking condition. Capital adequacy ratio is based on the historical cost accounting, hence, it is not accurate. These were further supported in the study of Laux and Leuz (2010); Hovakimian and Titman (2001); Gallardo (2005); Linsmeier (2011); Quintilla, Tiu, and Torres (2014). Empirical findings show that reliance on historical cost accounting provides deceptive gauge of total bank risk. To truly protect the interests of creditors, the use of realizable value or market value accounting has been recommended by the authors.

Research disclosed that there is a dearth of foreign and local literature dealing with the impact of insolvency on the recoveries of creditors' claims against closed banks. Hence, this paper serves as a pioneering study in the field of bank liquidation. In this endeavor, this paper attempted to bridge the gap between the time the bank is closed up and the time of asset distribution focusing on the recoveries of the creditors' claims against the assets of closed banks under Philippine context. There are two main goals of this paperminimization of creditors' losses and expeditious recoveries of creditors' claims against assets of closed banks. To address the said objectives, it is significant to determine the selected insolvency indicators and their impact on the recoveries of creditors' claims against the assets of closed banks under Philippine context. Hence, this paper tested the following propositions:

H1: Capital to estimated realizable value of assets ratio has no significant impact on the recoveries of creditors' claims against the assets of closed banks.

H2: Capital to book value of assets ratio has no significant impact on the recoveries of creditors' claims against the assets of closed banks.

H3: Debt to assets ratio has no significant impact on the recoveries of creditors' claims against the assets of closed banks.

H4: Capital adequacy ratio has no significant impact on the recoveries of creditors' claims against the assets of closed banks.

\section{Research Design}

\section{Research Framework}

The research framework of the study is based on section 30 of Republic Act No. 7653 or the New Central Bank Act, the theory on capital structure, and the investment theory. In the Philippines, there are two bank regulators, namely BSP as the primary regulator and PDIC as co-regulator. Each has a significant role to portray in fostering depositors confidence in the Philippine banking system.

The proposed paradigm of the conceptual framework is shown in Figure 1. In this model, the MB of the BSP is vested with the exclusive authority to allow the continued operations of safe and sound banks, place banks under receivership found falling under any of the grounds for closure provided under section 30 of the New Central Bank Act and section 53 of the General Banking Law of 2000 and designate PDIC as receiver, 
and if MB finds PDIC's recommendation to rehabilitate or liquidate a bank under receivership within 90 days as meritorious, it approves the rehabilitation or liquidation of the closed bank and appoints PDIC as a liquidator.

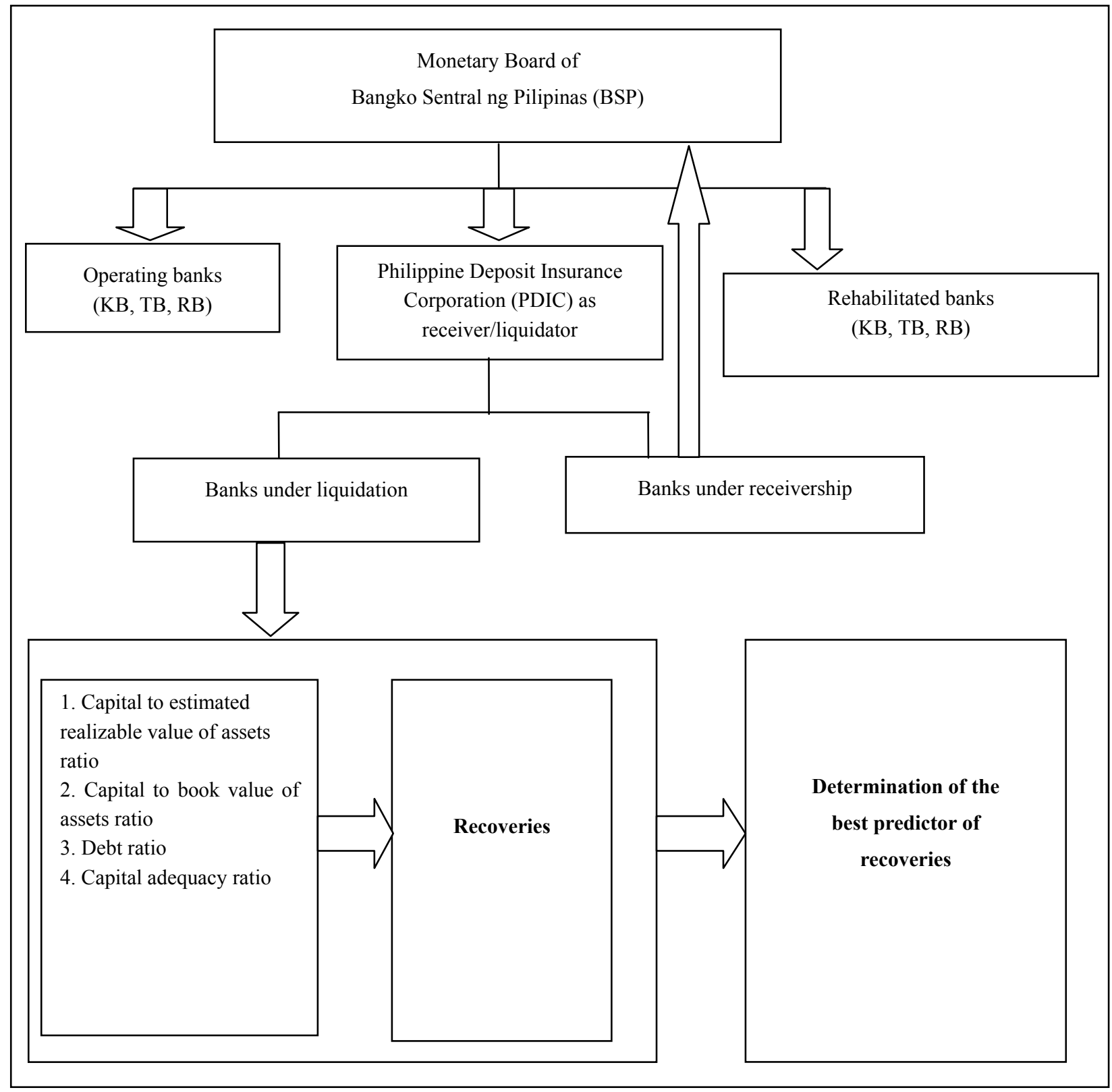

Figure 1. Research framework.

The authority of the MB encompasses operating banks, PDIC, and rehabilitated banks. Thus, an arrow is pointing to each other. PDIC as a receiver/liquidator connects the banks under receivership and under liquidation. The banks under receivership can be recommended by the receiver to the MB to be rehabilitated or liquidated. Hence, the paradigm shows the arrow pointing upward from banks under receivership. If the receiver recommends the bank to be liquidated, the MB orders its liquidation and appoints PDIC to be the liquidator. 
Banks under liquidation connects an arrow with the box containing the independent and dependent variables. The study focuses on the impact of insolvency on the recoveries of creditors' claims against the assets of the closed banks. As such, the selected insolvency indicators that were used to determine their significant impact to recoveries are capital to estimated realizable value of assets ratio, capital to book value of assets ratio, debt to assets ratio, and capital adequacy ratio. The ratios are used as independent variables and recoveries are the dependent variable. These selected insolvency indicators were subjected to statistical treatment using Pearson correlation, simple linear regression and ANOVA univariate to establish a link to recoveries. Hence, there is an arrow pointing to recoveries.

The independent variables were used as indices to validate recoveries on creditors' claims against closed banks' assets. All the independent and dependent variables were then enclosed in a box with an arrow pointing to the output that would determine the best predictor of recoveries.

\section{Research Methods}

\section{Research Subject}

The subjects for the present study are selected insolvency indicators of closed banks such as capital to estimated realizable value of assets ratio, capital to book value of assets ratio, debt to assets ratio, and capital adequacy ratio. Data from 1961 to 2011 are used for this paper.

\section{Regression Analysis, ANOVA Test and $\boldsymbol{F}$-test in Regression}

This study adopts regression analysis as its statistical technique to develop a mathematical equation (Doane \& Seward, 2009). The variable that is being explained or analyzed is the recovery, while the independent variables or predictors are the selected insolvency indicators. This paper uses the simple linear regression model with one predictor. Statistical package for social science (SPSS) Version 11.5 is used to calculate the value of the slope and the intercept of the said model. This paper arrives at a fitted regression equation/model as shown in Table 1. Before using the model for prediction purposes, this paper proved the model's goodness-of-fit by using the ANOVA test and $f$-test. Table 2 shows the summary of regression results for recoveries.

By empirical evidence, findings reveal that capital to estimated realizable value of assets ratio has a significant impact on recoveries of the creditors' claims against closed banks. The dependent variable or response that is being explained in this case is recovery, while the independent variable/predictor/regressor is the percent of capital to estimated realizable value of assets. Findings show that using the $f$-test in regression, $p$ value registered a moderate correlation with a significance level of 0.032 , which means that ERVA has the power to determine recoveries. Using the ANOVA test, the model has a good fit, since the regression sum of the squares is greater than its residual sum of squares.

Table 1

Regression Model

\begin{tabular}{ll}
\hline Selected insolvency indicators & Regression models \\
\hline 1. Capital to estimated realizable value of assets (ERVA) & Recovery $=270.362-91.348 \times$ PCT capital to ERVA \\
2. Capital to book value of assets (BVA) & Recovery $=342.161-123.280 \times$ PCT capital to BVA \\
3. Liabilities to estimated realizable value of assets (ERVA) & Recovery $=179.014+91.348 \times$ PCT Liabilities to ERVA \\
4. Liabilities to book value of assets (BVA) & Recovery $=218.881+123.280 \times$ PCT Liabilities to BVA \\
5. Capital adequacy ratio (CAR) & Recovery $=477.358-321.505 \times$ CAR \\
\hline
\end{tabular}


Table 2

Summary of Regression Results for Recoveries

\begin{tabular}{llll}
\hline $\begin{array}{l}\text { Dependent } \\
\text { variable/response }\end{array}$ & Independent variable/predictors & $\begin{array}{l}\text { Sig. } \\
(f)\end{array}$ & Remarks \\
\hline Recovery & Capital/ERVA ratio & 0.032 & Moderate degree of influence, significant predictor of recovery \\
Recovery & Capital/book value of assets ratio & 0.532 & Poor degree of correlation, weak predictor of recovery \\
Recovery & Debt/assets (ERVA) ratio & 0.032 & Moderate degree of influence, significant predictor of recovery \\
Recovery & Debt/assets (BV) ratio & 0.532 & Very weak correlation, not relevant predictor of recovery \\
Recovery & Capital adequacy ratio & 0.193 & Poor degree of correlation, weak predictor of recovery \\
\hline
\end{tabular}

The debt to assets ratio measures the percentage of the total assets funded by the creditors. It indicates the degree of leverage of a firm. The higher the ratio is, the higher the risk will be. The researchers classified the assets into two: (1) estimated realizable value of assets (ERVA) and (2) book value of assets (BVA). Findings showed that using the $f$-test in regression, the $p$-value registered a moderate correlation with a significance level of 0.032, which means it can be used as a predictor of recoveries. Employing the ANOVA test in regression, the model has a good-fit, since the regression sum of the squares is larger than its residual sum of squares. On the other hand, the debt to assets ratio with respect to book value has an opposite effect as compared to ERVA. Results showed that the $p$-value registered a weak correlation with significance level of 0.532 . These represent a poor correlation and a weak predictive power in determining the recoveries. The ANOVA test also supports this contention that the candidate predictor (capital to book value of assets ratio) fails to significantly explain the response. Hence, this is not a significant predictor of recovery.

Capital adequacy ratio (CAR) is a quantitative measurement used by BSP to regulate bank's capital. This is indicative of a bank's financial strength. However, the basis of this ratio is the book value or historical costs. In the event of bank closure, the book value of assets dramatically drops as compared to its realizable value of assets. Employing the book value gives a positive CAR which is misleading as contrasted to CAR with respect to ERVA. Results show that employing $f$-test in regression, the $p$-value registered a weak correlation with a significance level of 0.193 , which means that it cannot be used as a predictor of recoveries. The ANOVA test results showed that it cannot significantly explain the response.

\section{Conclusions}

This study aims to determine the impact of selected insolvency indicators on the recoveries of creditors' claims against closed banks under Philippine context. While there is a dearth of foreign and local literature dealing with the impact of selected insolvency indicators on the recoveries of creditors' claims against closed banks under liquidation, the researchers pursued this subject to recommend modifications in the Philippine traditional bank's closure procedures to minimize the losses imposed on the creditors. Table 1 shows the summary of regression results, while Table 2 shows the summary of bivariate regression for recoveries.

Findings show that insolvency indicators which have a significant impact on recoveries of the creditors' claims against the assets of closed banks include capital to ERVA ratio and debt to assets ratio (with respect to ERVA) ratio. It is worth noting that ERVA and non-book value registered a statistical link with recovery.

With this empirical evidence, the researchers recommend the modifications stated below and other courses of actions that will be beneficial to the best interest of uninsured depositors, creditors, and the general public: 
(1) Closing a bank if its liabilities to realizable assets ratio exceed $96 \%$. For the minimization of losses imposed on uninsured depositors and creditors of closed banks, section 30 (b) of Republic Act No. 7653 or the New Central Bank Act (which states that if MB finds that a bank has insufficient realizable assets to meet its liabilities, it may forbid the institution from doing business in the Philippines), should be amended to read as follows - section 30 proceedings in receivership and liquidation: Whenever xxx, the MB finds that a bank or a quasi-bank... or has liabilities to realizable assets ratio, as determined by Bangko Sentral, exceeding 96\%.

The foregoing recommendation can be validated by the above results wherein capital to ERVA ratio and debt to assets ratio is the best predictor of recoveries. Hence, these ratios are very useful in making sound decisions in bank liquidation.

(2) Amending the word "may" to "shall". At present, the MB has the option to close or not to close a bank despite the presence of legal grounds for placing a bank under receivership which is explicitly provided for under section 30 of the New Central Bank Act and section 53 of the General Banking Law of 2000. To divest the MB of such option, the word "may" under the two laws should be amended by the word "shall". Thus, section 30 of the New Central Bank Act should be amended to read as follows: section 30 ...the MB shall summarily and without need for prior hearing forbid the institution from doing business in the Philippines and designate the PDIC as receiver of the banking institution. Likewise, section 53 of RA 8791 should also be amended to read as follows: section 53 in case a bank xxx, the MB shall summarily and without need for prior hearing close such banking institution and place it under receivership of the PDIC.

(3) Inclusion of the fair market value of the bank's assets in the audit report of independent bank auditors. To correctly assess the financial condition and performance of banks, the MB should require accredited independent auditors hired by the banks to conduct regular audit to incorporate in their audit reports the fair market value of the bank's assets. The fair market value as mentioned in several foreign journals results in a timely accurate valuation of assets and liabilities.

(4) Emphasis on ERVA and liabilities by the receiver. In making recommendation to the MB whether to rehabilitate or liquidate a bank under receivership, it is recommended that the receiver should pay particular attention to (1) the two selected indicators of bank insolvencies: capital to estimated realizable value of assets ratio and debt to ERVA ratio; and (2) the two balance sheet accounts having significant degrees of influence to capital: ERVA and liabilities.

\section{References}

Bautista, M. S. G. (2005). The past performance of the Philippine banking sector and challenges in the post crisis period. Quezon City: University of the Philippines.

Diamond, D., \& Rajan, R. (2000). A theory of bank capital. Journal of Finance, 4(6), 2431-2465.

Doane, D., \& Seward, L. (2009). Applied statistics in business and economics (2nd ed.). New York: McGraw-Hill.

Gallardo, M. (2005). BSP, PDIC and the banking institutions: Fostering depositors' confidence in the Philippine banking system (Doctoral dissertation, University of the East, 2005).

Hogan, W., \& Sharpe, I. (1990). Risk based capital adequacy of Australian banks. Australian Journal of Management, 15(1), 177-201.

Hovakimian, O., \& Titman, S. (2001). The debt-equity choice. Journal of Financial and Quantitative Analysis, 36, 1-24.

Kaufman, G. (2004). FDIC losses in bank failures: Has FDICIA made a difference. Economic Perspectives, 1, 2-40

Laux, C., \& Leuz, C. (2010). Did fair-value accounting contribute to the financial crisis? Journal of Economic Perspectives, 24(1), 93-118.

Linsmeier, T. (2011). Financial reporting and financial crises: The case for measuring financial instruments at fair value in the financial statements. Journal of Accounting Horizons, 25(2), 409-417. 
Mitchener, K. J. (2005). Bank supervision, regulation and instability during the great depression. Journal of Economic History, 65(1), 152-185.

Moore, J. (2011). Bank performance prediction during the "great recession" of 2008-2009: A pattern-recognition approach. Academy of Banking Studies Journal, 10(2), 87-103.

Morris, S., \& Shin, S. H. (2008). Financial regulation in a system context. Economic Activity, 1, 129-261.

Philippine Deposit Insurance Corporation. (2003). PDIC: 40 years and beyond. Makati City: Philippine Deposit Insurance Corporation.

Quintilla, M., Tiu, T., \& Torres, E. (2014). Recoveries of creditors' claims against closed banks under Philippine setting. International Journal of Social Sciences and Entrepreneurship, 1(10), 1-11.

Samad, A. (2011). Is capital inadequacy a factor for bank failure? Evidence from US banking. Journal of Accounting and Finance, 11(4), 105-110.

Vyas, R. K., Singh, M., \& Yadav, R. (2008). The impact of capital adequacy requirements on performance of scheduled commercial banks. Asia-Pacific Business Review, 4(2), 74-81. 